\title{
Career Decision-Making Characteristics of Primary Education Students in Greece
}

\author{
Despina Sidiropoulou-Dimakakou ${ }^{1}$, Kostas Mylonas $^{1}$, Katerina Argyropoulou ${ }^{1} \&$ Nikos Drosos ${ }^{1}$ \\ ${ }^{1}$ Department of Psychology, National and Kapodestrian University of Athens, Greece \\ Correspondence: Despina Sidiropoulou-Dimakakou, Department of Psychology, National and Kapodestrian \\ University of Athens, Panepistimiopolis, Ilissia 15784, Athens, Greece. Tel: 30-210-727-7571. E-mail: \\ dsidirop@psych.uoa.gr
}

Received: February 19, 2013 Accepted: March 25, 2013 Online Published: April 26, 2013

doi:10.5539/ies.v6n5p22 URL: http://dx.doi.org/10.5539/ies.v6n5p22

The research was funded by the University of Athens "Kapodestrias" Research Project.

\begin{abstract}
The present study aims at investigating career decision-making process of $6^{\text {th }}$ grade students with the use of the Childhood Career Decision-Making Questionnaire (CCDMQ). CCDMQ offers scores for the following three decision-making dimensions: (a) Concerns/ fears regarding career future, (b) Investment on decision-making process, and (c) Knowledge of the World of Work. The study reports the psychometric properties and the results of an exploratory factor analysis of the CCDMQ in a sample of $5316^{\text {th }}$ grade students in the region of Attica, Greece. The implications for future research and for career guidance are discussed.
\end{abstract}

Keywords: career decision-making skills questionnaire, career guidance activities, elementary school students

\section{Introduction}

Although life span theories acknowledge the importance of career development throughout the life span, career development research lacks an explicit focus on children (Whiston \& Brecheisen, 2002; Wood, \& Kaszubowski, 2008;). There are relatively few data regarding occupational knowledge of elementary school students (Walls, 2000), despite the theorists' general agreement that career development begins in childhood and continues throughout the life span. According to Hartung, Porfeli, and Vondracek's (2005) review of children's career development research has been largely focused on what children know about the world of work rather than on how they learn this information. Indeed, most research reviews conclude that career development in childhood is a complex interplay among attributes, behaviour and the environment (e.g., Gysbers, 1996) without reporting on such research. The $21^{\text {st }}$-century workforce requires individuals who are flexible thinkers, effective problem solvers, and lifelong learners. Consequently, it is imperative to gain a better understanding of the childhood decision-making process and to facilitate the development of decision-making skills to better prepare children for their life in the future (Johnson, 2000). In other words, it is important for them to develop decision-making skills and to gain a meaningful understanding for their future career choices.

Career guidance in the elementary school is not intended to force children to make premature choices but to avoid premature closure of future options. Early choices may be unwise in the sense that abilities, competences, and values are not fixed, and choices may be based on highly inaccurate assessments of competence (Sprinthall, \& Collins, 1984). As researchers emphasize, career related learning in the elementary school should "focus on students' awareness of educational, occupational and other choices that will be available as they proceed through school and into the adult world, of ways to anticipate and plan for them; and of the relation between work habits, abilities and interests, and related characteristics" (Herr, Crammer, \& Niles, 2004, pp. 334). Hartung, Porfeli, and Vondracek, (2005) conclude in their review that there is a need to change perceptions of children's career development from a passive to an active process in which children engage with the world of work. To accomplish these goals it is essential that career guidance activities in the elementary school become an integral part of school academic planning and transition process. Such activities might benefit from incorporating approaches such as the support of student's career development and career decision- making and the understanding of how current choices and planning affect their future (Wonacott, 2002). 
In Greece career guidance programs in elementary school are not based on classroom instruction but mostly on curriculum infusion techniques and on group activities. Attention is paid by teachers to career relevant learning; they use a wide variety of activities which help children to develop an awareness of themselves and the world of work.

The aim of the present study is to examine a number of dimensions related to career decision-making in a sample of $6^{\text {th }}$ grade students. Based on the results of this research we discuss the implications for future research and for career guidance in primary education.

\subsection{Career Development in Childhood}

Super (1980) identified the ages before 14 as the tentative period in which children start thinking about careers and themselves. According to Ginzberg (1996) children in the early school years use fantasy in their play and act out in a variety of adult roles without any risk and have fun doing it. Between ages 9 and 13 children enter into a second phase of circumscription in which they begin to rule out occupations requiring effort beyond their view of their general ability level (Gottfredson, 2002). Children begin to develop their vocational self-concept, their career values and, up to the age of 12 most of the children are able to make some pilot career choices and justify these choices (Seligman, 1994). Social cognitive career theory (SCCT) (Lent, Brown, \& Hackett, 1994) emphasizes the importance of learning in childhood's interest development. Work by Lent and others (1994) provide the value of repeated practice, modeling, and feedback based on significant others that foster children to "develop skills, adopt personal standards, estimate their abilities, and form beliefs about likely outcomes of performing certain tasks" (p. 89). For instance, there has been substantiation for the critical role of parents and the influence of family relations in children's career development (Trice, Hughes, Odom, Woods, \& McClellan, 1995), the influence of social valuation on children's occupational aspirations (Helwing, 2001) and the decreasing role of fantasy and the increasing realism in occupational aspiration as children develop.

Career guidance counselors should take into consideration children's developmental stages, in order to be more effective (Seligman, 1994). According to Havighurst (1972) the elementary school years encompass developmental tasks, which include (a) achieving personal independence, (b) developing fundamental skills toward achieving in school, (c) becoming concerned about the future, learning to plan for the future, developing a scale of values and positive attitudes toward social group and work. The six goals associated with the accomplishment of required tasks for the career development of elementary school students are: (a) to develop a broad, flexible, and satisfying sex role identity, (b) to develop attitudes that are conducive to competence, cooperation, and achievement, (c) to develop self-awareness and a positive self-concept, (d) to acquire knowledge about workers, their roles, and the value of work, (e) to develop some understanding of the relationship of interests and values to occupational choice, (f) to develop an awareness and appreciation of one's interests, values, abilities, and personal qualities (Drummond \& Ryan, 1995, p.79). Consequently, the elementary school years encompass developmental tasks associated to the career development (Schultheiss, \& Stead, 2004), as students become able to develop a clear concept regarding occupations and to gain a meaningful understanding of career significance in social life.

\subsection{Career Guidance in the Elementary School}

Career education is most typically thought of in conjunction with middle and high school curriculum and less often within the scope of primary education. Yet critical components of career education, such as self-knowledge and awareness of the larger community and world in which one lives, are emphasized in many ways to younger children in their classrooms. Freeman (1994) has stressed that career guidance in elementary school is associated with basic skills and attitudes that children should acquire to deal effectively with daily life, to make the transition into the middle/junior high school and to start developing an educational plan to insure their academic growth and continuing career development. Without career education, students have unrealistic perceptions of careers due to a lack of knowledge and poor decision making (Ediger, 2000). Therefore career guidance in elementary school should be considered as a dynamic and creative process that can be incorporated in various courses of the curriculum. The elements of vocational exploration (e.g. curiosity, information, exploration, planning) are the top career development needs for the philosophy and practice of career guidance in elementary school. Research findings suggest that the goals of career guidance activities in elementary school include objectives related to career exploration, knowledge of the world of work, awareness of self, decision-making skills, understanding the meaning of various concepts relevant to the labor market, and awareness of competencies needed as building blocks for positive career development (Campbell \& Dahir, 1997; Bobo, Hildreth \& Durodoye, 1998; Flum \& Blustein, 2000).

Elementary school teachers play a significant role in the implementation of career guidance activities. They build 
self-awareness, family awareness, school awareness, community awareness, career/ work awareness, attitude development, skill development, decision making strategies, and self-worth (Ediger, 2000). Recent research in Greece outlined that teachers in primary education schools should aim at: (a) developing students' career awareness and facilitating the formation of values, attitudes, and interests (Argyropoulou, Papaioannou, \& Touloumakos, 2005; Sidiropoulou-Dimakakou, Krassas, \& Touloumakos, 2005); (b) developing students' skills for understanding and using career information by identifying the difficulties and the working conditions of the various occupations (Sidiropoulou-Dimakakou, Argyropoulou \& Papaioannou, 2009); (c) introducing to children the basic concepts of labor market and helping them to realize that each profession requires different abilities and skills (Kassotakis, 2002). It is, also, stated that teachers should: (a) provide opportunities for students to express their beliefs about themselves in relation to various occupations (Magnuson \& Starr, 2000); and (b) facilitate children's understanding of how to make decisions and choose alternatives related to tentative educational and career goals (Freeman, 1994). Lessons, written exercises, journals and on-line Internet sources may be utilized by teachers in order to help students articulate the development of a vocational self and career goals (Lapan, 2004; Silverstein, 2005).

Parental support is of great importance as well. Parents can collaborate with teachers and contribute to career guidance programs, provide opportunities and experiences for their children to develop decision-making skills, and help their children to develop an interest in career awareness (Isaacson \& Brown, 2000; Sidiropoulou-Dimakakou, Mylonas, \& Argyropoulou, 2003).

\section{Method}

The present study aims at examining the following three relevant to career decision-making dimensions of primary education students: (i) concerns/ fears regarding career future, (ii) investment in decision making process, and (iii) knowledge of the world of work. Differences at the extents of these dimensions are expected as a result of students' demographic variables (e.g. students' gender, parents' educational level). The findings of the present study should be regarded as a first stage exploratory attempt. We believe that the results may contribute to the understanding of childhood career development and decision-making process and have practice implications for the design of career guidance activities which focus on the needs of elementary school children.

\subsection{Participants}

The sample consisted of $5316^{\text {th }}$ grade students in the region of Attica, Greece. The particular class was selected because in the Greek educational system $6^{\text {th }}$ grade is the last class of the elementary school and has a transitional character. This is also a period of life when students become able to make some pilot career choices and justify them. With respect to gender participants were 266 (50.1\%) male and 265 (49.9\%) female.

\subsection{Instrumentation}

We used the Childhood Career Decision-Making Questionnaire (CCDMQ) which consisted of 27 items representing cognitive (eg. lack of information) and affective dimensions (eg. hope or fear) in making career decisions (Sidiropoulou-Dimakakou, Mylonas, Argyropoulou, 2008; Sidiropoulou-Dimakakou, 2009). CCDMQ offers scores for the following three factors: a) Concerns/ fears regarding career future (8 items), b) Investment on decision-making process (13 items), and c) Knowledge of the World of Work (6 items). Furthermore, the psychometric properties of CCDMQ were adequately assessed on a large-scale research with a sample of 1020 $6^{\text {th }}$ grade students that confirmed its good psychometric characteristics (Krassas, 2012). The estimated internal consistency coefficients of the aforementioned categories of CCDMQ in this study were 0.69,0.62, and 0.61 respectively.

Several researchers have presented models for making career decisions supporting that decision-making is not a purely logical process but emotionally charged. Values, motivations, biases affect the person analyzing and processing information, while emotions are present, as the person is in a state between hope and fear (Gati \& Tal, 2008; Kelly \& Lee, 2002). Furthermore, the lack of information about the individual's personality such as interests, abilities and aspirations impede career decision- making while the lack of information on occupations, their ways of acquiring information but also the difficulties arising from the influence of significant others affect the career decision-making process or choice (Germeijs \& De Boeck, 2003; Saka, Gati \& Kelly, 2008). It is assumed that when other people (family members or teachers) influence or consulting individuals in taking decisions then emotions, such as anger, guilt, pleasure, play an important role in decision-making process (Zeelenberg, Nelissen, Breugelmans \& Pieters, 2008). Therefore, the review of previous research highlights the cognitive deficits and the affective interference as the two influential dimensions (Chartarnd, Robins, Morill, \& Boggs, 1990), which have important implications for developing appropriate interventions in career decision-making (Kelly \& Lee, 2002). 
CCDMQ assesses the view of primary education students about issues relevant to career decision-making process. Starting with the theoretical background in career decision-making and taking into account the developmental tasks related to career development, which a child is expected to accomplish in the school age, it was decided to construct a new multidimensional measure which investigates: whether the student has concerns/ fears regarding his/ her career future; if the student has informed approach to vocational choice; and whether the student invests career decision-making process. These issues are among the central constructs involved in career decision-making in the school age.

Following acceptable standards for scale construction (Spector, 1992) we first generated an initial pool of 60 items representing aspects of the aforementioned decision-making dimensions. The items were inspected by the four authors and a short number of career counselling practitioners, and 20 items were deleted from the list because there wasn't absolute agreement. The remaining 40 items formed the basis of the first version of the questionnaire (Sidiropoulou-Dimakakou, Mylonas, Argyropoulou, 2008; Sidiropoulou-Dimakakou, 2009). Based on pilot studies with a sample of $3546^{\text {th }}$ grade students and using various statistical methods (including exploratory factor analysis, item-scale correlations, and internal consistency reliability) the 13 items with the lowest psychometric properties were deleted. In the present study we use the last version of CCDMQ with 27 items, written in a 2-point scale of YES and NO. The 27 statements of the scale are listed in table 1 and some examples are: "School knowledge prepares me for my future job", "Before choosing an occupation I need to think hard in order to understand what kind of job I would like to have", "In school I learn useful thing for my future job", or "When I think of my future job, I feel that I need help". An impromptu questionnaire consisted of 12 items was used to assess gender and parental information.

\subsubsection{Administration of the Instruments and Scoring}

The CCDMQ was administrated in class by the researchers or by the teacher of the class who has been trained by the researchers. The Greek Pedagogical Institute approved the research and gave permission to administrate the questionnaire to the students. Participation was voluntary and this was made clear to the students. They were asked to participate in a study about career decision-making by filling out the research questionnaire. They were instructed to answer all 27 questions, shown in Table 1, by circling the responses on a 2-point scale (YES/NO) for each item, and were asked not to put their name on the questionnaire to assure anonymity.

\section{Results}

\subsection{Factor Analyses}

Table 1. Factor analysis (PCA) for the 27 items of the Childhood Career Decision-Making Questionnaire

\begin{tabular}{llll}
\hline & \multicolumn{2}{l}{ Factors } \\
& 1 & 2 & 3 \\
\hline - When I think of my future job, I feel concerned. & $\mathbf{0 . 6 7}$ & 0.04 & 0.01 \\
- When I think of my future job, I feel fear. & $\mathbf{0 . 6 4}$ & -0.04 & -0.10 \\
- When I think of my future job, I feel calm. & $\mathbf{- 0 . 6 2}$ & 0.03 & 0.18 \\
- When I think of my future job, I feel confident. & $\mathbf{- 0 . 6 0}$ & 0.04 & 0.17 \\
- When I think of my future job, I feel that I need help. & $\mathbf{0 . 5 6}$ & 0.15 & 0.00 \\
- It is difficult for me to think of my future job. & $\mathbf{0 . 5 0}$ & 0.02 & -0.20 \\
- It is easy for me to remain concentrated on my targets and to realize my plans. & $\mathbf{- 0 . 3 7}$ & 0.02 & 0.16 \\
- Many of the problems that I face are very complicated and I cannot solve them. & $\mathbf{0 . 3 5}$ & -0.13 & 0.07 \\
- School provides me knowledge that will prepare me for my future education. & 0.03 & $\mathbf{0 . 5 3}$ & -0.00 \\
- Before choosing an occupation, I need to know my skills and interest, in order to & 0.09 & $\mathbf{0 . 5 2}$ & -0.01 \\
understand what kind of job would suit me better. & & & \\
- To succeed in my future job I need good grades at school. & 0.14 & $\mathbf{0 . 4 4}$ & -0.05
\end{tabular}


- Before choosing an occupation I need to think hard in order to understand what kind of job I would like to have.

$0.16 \quad 0.44 \quad 0.06$

- To make career choices I have to know in which subjects I am good.

$-0.06$

$0.44-0.11$

- School knowledge prepares me for my future job.

$\begin{array}{lll}-0.09 & \mathbf{0 . 4 3} & 0.04\end{array}$

- To solve a problem I have first to define what exactly the problem is.

$0.01 \quad \mathbf{0 . 4 0} \quad 0.07$

- To choose my future job I have to gather much information.

$\begin{array}{lll}0.14 & \mathbf{0 . 3 9} & 0.07\end{array}$

- When facing a problem I think of many alternative solutions, in order to choose the best one.

$-0.14 \quad 0.39 \quad-0.11$

- I know my parents' occupations.

$\begin{array}{lll}-0.15 & \mathbf{0 . 3 8} & -0.01\end{array}$

- Having spare time is very important for me.

$\begin{array}{lll}-0.00 & \mathbf{0 . 3 8} & 0.13\end{array}$

- I can achieve better grades at school by trying more.

$\begin{array}{lll}-0.18 & \mathbf{0 . 3 7} & 0.19\end{array}$

- In school I learn useful thing for my future job.

$\begin{array}{lll}-0.12 & \mathbf{0 . 3 7} & 0.01\end{array}$

- I know the various different occupations.

$\begin{array}{lll}-0.06 & -0.00 & \mathbf{0 . 7 2}\end{array}$

- I know the various occupations where people have to work with machines.

$\begin{array}{lll}0.00 & -0.07 \quad \mathbf{0 . 6 7}\end{array}$

- I know the places where each job is conducted.

$\begin{array}{lll}-0.13 & 0.08 & \mathbf{0 . 6 2}\end{array}$

- I know the various occupations that require cooperation with other people.

$\begin{array}{lll}-0.08 & 0.00 & \mathbf{0 . 5 7}\end{array}$

- I can describe the reasons for which people choose their job.

$\begin{array}{lll}-0.08 & 0.00 & \mathbf{0 . 3 9}\end{array}$

- I am able to solve even hard life problems.

$\begin{array}{lll}-0.13 & 0.17 & \mathbf{0 . 3 6}\end{array}$

Variance explained (total: $27.51 \%$ )

$10.04 \% \quad 9.16 \% \quad 8.30 \%$

Internal Consistency Coefficients

0.69

0.62

0.61

Exploratory factor analysis was conducted to categorize the questionnaire's items into larger homogeneous groups, in order to better describe the internal structure of the students' responses. Factor analysis included 27 items for the 531 students. Principal Component Analysis with varimax rotation was used as extraction method. The final solution (having as the cut point loading the 0.35 ) revealed the three (3) factors we expected, to which $27.51 \%$ of the variance can be attributed. For this analysis $\mathrm{KMO}=0.72, \chi^{2}$ for the Bartlett's test of sphericity $=$ $1.783 \mathrm{E} 3(\mathrm{df}=351, \mathrm{p}<0.001)$. In table 1 all loadings of the measurements in the three factors based on this solution are presented.

Based on the content of item loadings, the three components were labelled as follows. Item examples are offered for each component.

Component 1, labelled Concerns/ fears regarding career future, included 8 items $(4,35,32,29,24,11,7,6)$ that represent the feelings of uncertainty and fear that student experiences when thinking of his/her career future (e.g., "When I think of my future job I feel concerned", or "It is difficult for me to think of my future job", or "It is easy for me to remain concentrated on my targets and to realize my plans").

Component 2, labelled Investment in decision making process consisted of 13 items (5, 40, 37, 30, 23, 13, 9, 17, $18,10,21,38,16)$ that assess the understanding of the career decision making process stages (gathering information about oneself and about the occupations, producing alternative solutions, and understanding of the relevance that school-based learning has to a future career) (e.g., "To choose my future job I have to gather much information", "When facing a problem I think of many alternative solutions in order to choose the best one", or "To make career choices I have to know in which subjects I am good").

The third component, labelled Knowledge of the World of Work, included 6 items $(31,27,19,15,20,22)$ that assess the level of knowledge that students believe they have about various occupations and their working conditions (e.g. "I know the various different occupations", "I can describe the reasons for which people choose their occupation"). 
Cronbach $\alpha$ coefficient for the CDSQ subscales are presented in Table 1. The estimates of internal consistency reliability were acceptable (Nunnally, 1978).

Table 2. Mean scores and standard deviations for the 3 factors of the Childhood Career Decision-Making Questionnaire

\begin{tabular}{lllllll}
\hline Factors & $\mathrm{N}$ & Min & Max & Mean* & SD & Variance \\
\hline Concerns/ fears regarding career future & 531 & 0.00 & 1.00 & 0.33 & 0.26 & 0.07 \\
Investment in decision making process & 531 & 0.31 & 1.00 & 0.89 & 0.13 & 0.02 \\
Knowledge of the World of Work & 531 & 0.00 & 1.00 & 0.64 & 0.27 & 0.07
\end{tabular}

$* 0=$ No (low level), 1 = Yes (high level)

As shown in table 2 we subsequently calculated the mean scores and standard deviations of the three decision-making categories. The minimum possible score in each category is 0 and represents low level of the factor while the maximum possible score is 1 and represents high level of the factor. The highest score was on Investment in decision- making process $(\mathrm{M}=0.89, \mathrm{SD}=0.13)$. Subsequently, a quite high score was achieved in Knowledge of the World of Work $(\mathrm{M}=0.64, \mathrm{SD}=0.27)$. Finally, the lowest score was on Concerns/fears regarding career future $(\mathrm{M}=0.33, \mathrm{SD}=0.26)$.

\subsection{Correlations}

Table 3. Pearson Correlations Coefficients of the 3 factors of Childhood Career Decision- Making Questionnaire and of parents' educational level for the 5316 th grade students

\begin{tabular}{llllll}
\hline \multicolumn{1}{c}{ Factors } & 1 & 2 & 3 & 4 & 5 \\
\hline Concerns/ fears regarding career future & 1 & -0.02 & $-0.28^{* *}$ & $-0.12^{* *}$ & $-0.14^{* *}$ \\
Investment in decision making process & & 1 & .08 & -0.01 & 0.02 \\
Knowledge of World of Work & & & 1 & $0.18^{* *}$ & $0.11^{*}$ \\
Father's educational level & & & 1 & $0.59^{* *}$ \\
Mother's educational level & & & & 1
\end{tabular}

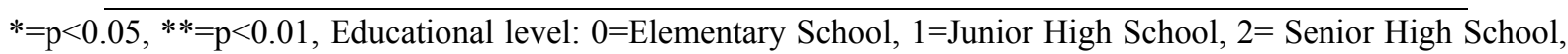
$3=$ University

In table 3 the correlations matrix between the three career decision-making categories scores (Concerns/fears regarding career future, Investment in decision-making process, and Knowledge of the World of Work) and parents' educational level are displayed. Concerns/ fears regarding career future is negatively correlated with father's and mother's educational level $(\mathrm{r}=-0.12, \mathrm{p}<0.01$, and $\mathrm{r}=-0.14, \mathrm{p}<0.01$ respectively), but the correlation is extremely low. Knowledge of the World of Work is positively correlated with students' father's and mother's educational level ( $\mathrm{r}=0.18, \mathrm{p}<0.01$, and $\mathrm{r}=0.11, \mathrm{p}<0.05$ respectively), but the correlation is extremely low as well. Finally, Investment in decision-making process is not correlated to parents' educational level.

To test the degree of independence of the 3 dimensions, we computed the intercorrelations between the 3 scale scores; these correlations are presented in Table 3. Consistent with Cohen's (1988) effect size classifications (i.e., $.10=$ small, $.30=$ medium, $.50=$ large), the correlations between the three CCDMQ components were small. In addition, Concerns/ fears regarding career future has a low but significant negative correlation with Knowledge of the World of Work $(\mathrm{r}=-0.28, \mathrm{p}<0.01)$. There is no other correlation between the three decision-making categories.

\subsection{Students' Gender}

One-way ANOVA were performed to determine whether there are gender differences at the level of career 
decision making factors.

Table 4. Mean scores and standard deviations for the 3 factors of the Childhood Career Decision-Making Questionnaire for male and female students

\begin{tabular}{lllll}
\hline Factors & Gender & $\mathrm{N}$ & Mean & $\mathrm{SD}$ \\
\hline Concerns/ fears regarding career future & Males & 266 & 0.32 & 0.25 \\
& Females & 265 & 0.33 & 0.27 \\
Investment in decision making process & Males & 266 & 0.87 & 0.13 \\
& Females & 265 & 0.90 & 0.13 \\
Knowledge of World of Work & Males & 266 & 0.64 & 0.28 \\
& Females & 265 & 0.63 & 0.27 \\
\hline
\end{tabular}

As shown in table 4 significant differences were found in Investment in decision-making process as a function of gender $[F(1,529)=6.69, p<0.01]$. Male students had significantly lower scores $(\mathrm{M}=0.87, \mathrm{SD} .=0.13)$ than female students $(\mathrm{M}=0.90, \mathrm{SD}=0.13)$.

\section{Discussion and Conclusion}

The absence of career related psychometric instruments for children has led to the development of CCDMQ in order to measure career decision-making characteristics of primary education students. We applied CCDMQ to Greek students and our results provide preliminary support for the reliability and validity of its scores. The results of this analysis largely supported our efforts to construct items consistent with the cognitive and emotional dimensions of career decision-making and the theoretical background of career development and choice in the school age. The components of factor analysis are consistent with theory and research (Chartarnd \& Robbins, 1990; Kelly \& Lee, 2002; Saka, Gati \& Kelly, 2008; Schultheiss, Palma, \& Manzi, 2002) and suggest that Greek primary education students could approach issues of decision-making in occupational terms.

Results of this study show that students of our sample seem to have a rather low level of uncertainty and fear regarding their future career. Moreover, they report a very high level of understanding about the career decision-making process stages, and, finally, they believe that they are informed about the various occupations and their working conditions. The results might conduct the social desirability, a fact which is obliged mainly to the age of the students and to the type of the questions. Additional research is needed to further assess career decision-making and its relevance in school age-children.

The finding of low correlations between the dimensions of the scale demonstrates that the 3 dimensions are distinct. This result is compatible with the conclusion that the 3 dimensions are independent and not mutually exclusive. Nevertheless, there were correlations among certain associated dimensions; for example, the correlations between Concerns/ fears regarding career future and Knowledge of the World of Work showing that students who are shined with fears regarding career future also tend to have limited knowledge of the world of work.

The low level of uncertainty and fear regarding the future career of the children may have a positive impact on their development, yet questions are raised regarding its cause. Current economic crisis creates concerns and fears about people's career future; however children seem to remain uninfluenced by this fact. Probably, this lack of concerns derives from an unrealistic point of view. It is possible that parents and/or teachers avoid talking in front of the children about their financial situation and problems as a way of "protecting" them against the "harsh" reality.

The finding that students report a very high level of understanding of the career decision-making process stages seems to be a very interesting one. It may show that children have realized the importance of identifying their interests, skills, and values, and they understand the interference between school-based learning and future career. This finding is consistent with other studies which suggest that career development learning is drawn from the whole school experience of the children (McMahon, Carroll, \& Gillies, 2001).

In addition, primary education students of our sample seem to believe that they have adequate knowledge of the 
various occupations, their working conditions and the criteria for choosing an occupation. It would be very interesting to investigate further whether children in Greece do actually have accurate knowledge of the occupations or they just think they do. Walls (2000) explored the occupational knowledge in elementary school and found that although occupational knowledge improved from the third to twelve grade, students continued to hold inaccurate views of the availability of jobs. Further, students seemed to have the least accurate information about occupations at the extreme ends of the spectrum on dimensions such as preparation time, earnings, cognitive requirements, and status. This could be the topic of a future study.

Results of the ANOVA conducted to explore the relationship between the CCDMQ subscales and gender indicated statistically significant gender differences in Investment in decision-making process with the male students to have significantly lower scores than female students. This difference may be associated with previous findings of higher consciousness of women in comparison to men (Costa, Terracciano, \& McCrae, 2001), and may have implications for early career education programs which will encourage boys to invest more effort in the decision-making process. It is possible that young girls may demonstrate more effort invested in career decision-making than boys and later make the final decision more slowly than men because they are more hesitant (Rassin \& Muris, 2005). Future studies should investigate whether controlling for levels of efforts invested in the decision-making process completely eliminates the gender difference in speed of making the final decision.

\subsection{Implication for Practice in School Settings}

There are a few practical implications for using this measure in school settings. Although there may be little urgency for children to make immediate occupational choices, it is imperative for them to develop an understanding of the relevance of school-based learning to their future career decision making. Hence, using psychometrically sound measurement tools, such as the CCDMQ, available to conduct needs assessments will assist in program planning and implementation and facilitate the development of effective career intervention programs.

Furthermore, if career counselling is viewed as decision-making counselling, one of the main roles of teachers and counsellors is to guide children through a process leading to making better career decisions. CCDMQ will allow for a more accurate, sensitive, and comprehensive appraisal of children' approach to career decision-making. This, in turn, may: (a) help children become aware of their career decision-making process and (b) help counsellors better tailor children face-to-face counselling to the child's career decision-making characteristics so as to increase the effectiveness of the intervention.

\subsection{Limitations}

More research is necessary to guide early developmental and preventive career intervention efforts for children. Although this study involved $6^{\text {th }}$ grade students, it seems appropriate to focus on younger students as well. Future research should also focus on identifying discrepancies in career development among subgroups of students as means of beginning to address inequities. Similarly, studies on educationally vulnerable groups could lead to educational approaches that assist in ameliorating gaps in academic achievement.

\section{References}

Argyropoulou, A., Papaioannou, Ch., \& Touloumakos, A. (2005, July). The educator as a person who affects the development of career self-awareness of students. Paper presented at the $27^{\text {th }}$ International School Psychology Colloquium. Athens, Greece.

Bobo, M., Hildreth, B. L., \& Durodoye, B. (1998). Changing patterns in career choices among African American, Hispanic, and Anglo children. Professional School Counseling, 1, 37-42.

Campbell, C. A., \& Dahir, C. A. (1997). The national standards for school counseling programs. Alexandria, VA: American School Counselor Association.

Chartrand, J. M., Robins, S. B., Morill, W. H., \& Boggs, K. (1990). Development and validation of the Career Factors Inventory. Journal of Counseling Psychology, 37, 491-501. http://dx.doi.org/10.1037//0022-0167.37.4.491

Cohen, J. (1988). Statistical power analysis for the behavioral sciences. Hillsdale, NJ: Lawrence Erlbaum.

Costa, P. T., Terracciano, A., \& McCrae, R. R. (2001). Gender differences in personality traits across cultures: Robust and surprising findings. Journal of Personality and Social Psychology, 81, 322-331. http://dx.doi.org/10.1037//0022-3514.81.2.322 
Drummond, R. J., \& Ryan, C. W. (1995). Career counseling: a developmental approach. Prentice-Hall, NJ: Englewood Cliffs.

Ediger, M. (2000, July). Vocational Education in the Elementary School. (ED442979) Opinion Papers.

Flum, H., \& Blustein, D. L. (2000). Reinvigorating the study of vocational exploration: A framework for research. Journal of Vocational Behavior, 56, 380-404. http://dx.doi.org/10.1006/jvbe.2000.1721

Freeman, B. (1994). Importance of the National Career Development Guidelines to school counselors. Career Development Quarterly, 42(3), 224-228. http://dx.doi.org/10.1002/j.2161-0045.1994.tb00937.x

Gati, I., \& Tal, S. (2008). Decision-making models and career guidance. In J. Athanasou, \& R. Van Esbroeck (Eds.), International handbook of career guidance (pp. 157-185). Berlin: Springer. http://dx.doi.org/10.1007/978-1-4020-6230-8_8

Germeijs, V., \& De Boeck, P. (2003). A measurement scale for indecisiveness and its relationship to career indecision and other types of indecision. European Journal of Psychological Assessment, 18(2), 113-122. http://dx.doi.org/10.1027//1015-5759.18.2.113

Gordon, E. (1999). Education and justice: A view from the back of the bus. New York: Teachers College Press.

Gottfredson, L. (2002). Gottfredson's theory of circumscription, compromise, and self-creation. In D. Brown, \& Associates (Eds.), Career choice and development (4th ed., pp. 85-148). San Francisco, CA: Jossey-Bass.

Gysbers, N. C. (1996). Meeting the career needs of children and adolescents. Journal of Vocational Education Research, 21, 87-98.

Hartung, P. J., Porfeli, E. J., \& Vondracek, F. W. (2005). Child vocational development: A review and reconsideration. Journal of Vocational Behavior, 66, 385-419. http://dx.doi.org/10.1016/j.jvb.2004.05.006

Havisghurst, R. (1972). Developmental tasks and education (3rd ed.). New York: D. McKay Co.

Helwig, A. A. (2001). A test of Gottfredson's theory using a ten-year longitudinal study. Journal of CareerDevelopment, 28, 77-95.

Herr, E., Cramer, S. H., \& Niles, S. G. (2004). Career Guidance and Counseling through the Life Span. Boston, MA: Pearson Education Inc.

Irving, B. A., \& Malik, B. (2005). Critical reflections on career education and guidance: Promoting social justice within a global economy. New York: Routledge Falmer. http://dx.doi.org/10.4324/9780203356951

Isaacson, L. E., \& Brown, D. (2000). Career information, career counseling and career development. Boston: Allyn and Bacon.

Johnson, L. S. (2000). The relevance of school to career: A study in student awareness. Journal of Career Development, 26, 263-276. http://dx.doi.org/10.1177/089484530002600403

Kassotakis, M. (2002). Information for studies and occupations. In M. Kassotakis (Ed.), Counseling and Career Guidance (pp. 279-315). Athens: Tipothito. (In Greek).

Kelly, K. R., \& Lee, W. C. (2002). Mapping the domain of career decision problems. Journal of Vocational Behavior, 41, 302-326. http://dx.doi.org/10.1006/jvbe.2001.1858

Krassas, S. (2012). Investigation of career life related characteristics development in $6^{\text {th }}$ grade students. Doctoral Dissertation. Athens: University of Athens - Faculty of Philosophy, Pedagogy, \& Psychology (In Greek).

Lapan, R. T. (2004). Career development across the K-16 years: Bridging the present to satisfying and successful futures. Alexandria, VA: American Counseling Association.

Lent, R. W., Brown, S. D., \& Hackett, G. (1994). Toward a unifying cognitive theory of career and academic interest, choice, and performance [Monograph]. Journal of Vocational Behavior, 45, 79-122. http://dx.doi.org/10.1006/jvbe.1994.1027

Magnuson, C. S., \& Starr, M. F. (2000). How early is too early to begin life career planning? The importance of the elementary school years. Journal of Career Development, 27, 89-101. http://dx.doi.org/10.1177/089484530002700203

McMahon, M., Carroll, J., \& Gillies, R. M. (2001). Career dreams: Occupational aspirations of year six children. Australian Journal of Career Development, 10, 25-31.

Nunnally, J. C. (1978). Psychometric theory. New York: McGraw-Hill. 
Rassin, E., \& Muris, P. (2005). To be or not to be indecisive: Gender differences, correlations with obsessive-compulsive complaints, and behavioural manifestation. Personality and Individual Differences, 38, 1175-1181. http://dx.doi.org/10.1016/j.paid.2004.07.014

Saka, N., Gati, I., \& Kelly, K. (2008). Emotional and Personality-Related Aspects of Career-Decision-Making Difficulties. Journal of Career Assessment, 16(4), 403-424. http://dx.doi.org/10.1177/1069072708318900

Schultheiss, D. E. P., \& Stead, G. B. (2004). Childhood Career Development Scale: Construction and psychometric properties. Journal of Career Assessment, 12, 113-134.

Schultheiss, D. E. P., Palma, T. V., \& Manzi, A. J. (2002, August). Career development in childhood: A qualitative inquiry. Paper presented at the Annual Meeting of the American Psychological Association, Chicago.

Seligman, L. (1994). Developmental career counseling and assessment. London: Sage.

Seligman, M., E., P. (1980). A learned helplessness point of view. In L. Rehm (Ed.), Behavior Therapy for Depression (pp.123-142). New York: Academic Press.

Sidiropoulou-Dimakakou, D. (2009). Career Assessment. Athens: Metaixmio (In Greek).

Sidiropoulou-Dimakakou, D., Argyropoulou, A., \& Papaioannou, Ch. (2009). Shaping career choices in primary education: Development and implementation of career guidance activities throughout the curriculum. Nea Paideia, 129, 31- 49. (In Greek).

Sidiropoulou-Dimakakou, D., Krassas, S., \& Touloumakos, A. (2005, July). The influence of school and family to the formation of career development of primary and secondary education students. Paper presented at the $27^{\text {th }}$ International School Psychology Colloquium. Athens, Greece.

Sidiropoulou-Dimakakou, D., Mylonas, K., \& Argyropoulou, A. (2003). Adolescents' perceptions for parental influences to their occupational choices. Review of Counseling and Guidance, 64-65, 95-108 (In Greek).

Sidiropoulou-Dimakakou, D., Mylonas, K., \& Argyropoulou, A. (2008, November). Psychometric investigation of $6^{\text {th }}$ grade primary education children concerning psychological factors related to career decision-making. Paper presented at the $2^{\text {nd }}$ Pan-Hellenic Conference of Cognitive Psychology. Thessaloniki, Greece (In Greek).

Silverstein, J. (2005). Just curious: Children's use of digital reference for unimposed queries and its importance in informal education. Library Trends, 54, 228-244. http://dx.doi.org/10.1353/lib.2006.0020

Spector, P. (1992). Summated rating scale construction. Newbury Park, CA: Sage.

Sprinthall, N. A., \& Collins, W. A. (1984). Adolescent psychology: A developmental view. Menlo Park, CA: Addison-Wesley.

Stead, G. B., Watson, M. B., Gallant, E., \& Sauls, F. A. (2001, August). Occupational Awareness Inventory: Psychometric properties among South African students. Paper presented at the Annual Meeting of the American Psychological Association, San Francisco.

Super, D. E. (1980). A life-span, life space approach to career development. Journal of Vocational Behavior, 16(30), 282-298. http://dx.doi.org/10.1016/0001-8791(80)90056-1

Super, D. E. (1990). A life-span, life space approach to career development. In D. Brown, L. Brooks, \& Associates (Eds.), Career choice and development: Applying contemporary theories to practice (2nd ed., pp. 197- 261). San Francisco: Jossey Bass.

Super, D. E., Savickas, M. L., \& Super, C. M. (1996). The life-span, life-space approach to careers. In D. Brown, L. Brooks, \& Associates (Eds.), Career choice and development (3rd ed., pp. 121-178). San Francisco, CA: Jossey-Bass.

Trice, A. D., Hughes, M. A., Odom, C., Woods, K., \& McClellan, N. C. (1995). The origins of children's career aspirations: IV. Testing hypotheses from four theories. Career Development Quarterly, 43, 307-322. http://dx.doi.org/10.1002/j.2161-0045.1995.tb00436.x

Walls, R. T. (2000). Vocational cognition: Accuracy of $3^{\text {rd }}, 6^{\text {th }}, 9^{\text {th }}$, and $12^{\text {th }}$ grade students. Journal of Vocational Behavior, 56, 137-200. http://dx.doi.org/10.1006/jvbe.1999.1716

Watson, M., \& McMahon, M. (2005). Children's career development: A research review from a learning perspective. Journal of Vocational Behavior, 67, 119-132. http://dx.doi.org/10.1016/j.jvb.2004.08.011 
Whiston, S. C., \& Brecheisen, B. K. (2002). Practice and research in career counseling and development-2001. The Career Development Quarterly, 51, 98-154. http://dx.doi.org/10.1002/j.2161-0045.2002.tb00596.x

Wonacott, M. E. (2002). Career passports, portofolios and certificates. (ERIC Document Reproduction Service No. ED 467241.

Wood, C., \& Kaszubowski, Y. (2008). The career development needs of rural elementary school students. The Elementary School Journal, 108, 431-444. http://dx.doi.org/10.1086/589472

Zeelenberg, M., Nelissen, R., Breugelmans, S., \& Pieters, R. (2008). On emotion specificity in decision making: Why feeling is for doing. Judgment and Decision Making, 3(1), 18-27. 